\title{
Prinsip dalam Berkontrak Pelaku Olahraga Sepakbola Profesional di Indonesia
}

\author{
Nurharsya Khaer Hanafie (a), Fatimah Hidayahni Amin (b), Ririn N. (c)
}

(a) Fakultas Ilmu Sosial dan Hukum, Universitas Negeri Makassar, nurharsya.khaer@unm.ac.id

(b) Fakultas Bahasa dan Sastra, Universitas Negeri Makassar, fatimah.hidayahni@unm.ac.id

(c) Fakultas Ilmu Sosial dan Hukum, Universitas Negeri Makassar, ririnnurfah@gmail.com

\begin{abstract}
Legal studies have two types of research, namely normative legal research and empirical legal research. According to Peter Mahmud Marzuki, normative legal research is a process to find a rule of law, legal principles, and legal doctrines to answer the legal problems faced. Normative legal research is carried out to produce new arguments, theories or concepts as prescriptions in solving problems at hand. The research of this article aims to find out the principles of contracting for professional football players so that professional sports players in entering into a business agreement can find the contract principles contained in contracts made by professional sports players. In theory, this article will examine the extent to which contracts in civil law that apply in general can be translated into contracts for professional sports players that will apply specifically or lex specialis because they contain elements of civil and business contracts in the form of a special contract that is characterized by a contract for Professional sports players, especially football
\end{abstract}

Keywords: contract principles, professional sports actors, sports law.

\section{Abstrak}

Penelitian dalam artikel ini bertujuan untuk membandingkan asas-asas kontrak dalam hukum perdata dan asas-asas kontrak bagi pelaku olahraga profesional dalam melakukan suatu perjanjian bisnis sehingga ditemukan asas-asas kontrak yang terdapat dalam kontrak yang dilakukan oleh pelaku olahraga profesional. Secara teori, artikel ini akan mengkaji sejauh mana kontrak dalam hukum perdata yang berlaku secara umum dapat diterjemahkan menjadi kontrak bagi pemain olahraga profesional yang akan berlaku secara khusus atau lex specialis karena mengandung unsur kontrak perdata dan bisnis ke dalam bentuk kontrak khusus yang ciri kontrak pemain olahraga professional.

Kata kunci: prinsip kontrak, , profesi pelaku olahraga, hukum keolahragaan.

\section{Pendahuluan}

Hukum kontrak merupakan bidang hukum yang sangat penting di era globalisasi terutama dalam mendukung kegiatan di sektor perdagangan dan transaksi bisnis baik di tingkat nasional maupun internasional, termasuk pula dalam bidang olahraga. Menyatukan hubungan antara para pihak dalam lingkup nasional dan internasional bukanlah persoalan yang sederhana. Hal ini menyangkut perbedaan sistem, paradigma, dan aturan hukum yang berlaku sebagai

\section{Jurnal}

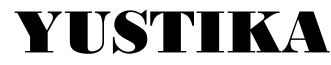

Media Hukum dan Keadilan

Fakultas Hukum Universitas Surabaya Vol. 24 No. 02, Desember 2021 E-ISSN: 2655-7479 suatu aturan yang bersifat memaksa untuk dipatuhi oleh para pihak di masing-masing negara.

Kontrak merupakan bagian yang melekat dari transaksi bisnis baik dalam skala besar maupun kecil, baik domestik maupun internasiomal. Fungsinya sangat penting menjamin bahwa seluruh harapan yang dibentuk dari janji-janji para pihak dapat terlaksana dan terpenuhi. Dalam hal terjadi pelanggaran maka terdapat kompensasi yang harus dibayar. Supaya kontrak menjadi sah maka para pihak harus sepakat terhadap segala hal yang terdapat di dalam perjanjian. Pada 
dasarnya kata sepakat adalah pertemuan atau persesuaian kehendak antara para pihak di dalam perjanjian. Seseorang dikatakan memberikan persetujuannya atau kesepakatannya jika ia memang menghendaki apa yang disepakati. (Sudargo Gautama : 1995)

Mariam Darus Badrulzaman melukiskan pengertian sepakat sebagai persyaratan kehendak yang disetujui (overeenstemende wilsverklaring) anta pihak-pihak. Pernyataan pihak yang menawarkan dinamakan tawaran (offerte). Dan pernyataan pihak yang menerima penawaran dinamakan akseptasi (acceptatie). (Mariam Darius Badrulzaman:2007) Dengan demikian dapat dikatakan bahwa penawaran dan akseptasi merupakan unsur yang sangat penting untuk menentukan lahirnya perjanjian.

Syarat sahnya kontrak, berkenaan baik mengenai subjek maupun objek perjanjian. Persyaratan yang pertama dan kedua berkenaan dengan subjek perjanjian dan pembatalan untuk kedua syarat tersebut adalah dapat dibatalkan (voidable). Sedangkan persyaratan ketiga dan keempat berkenaan dengan objek perjanjian dan pembatalan untuk kedua syarat tersebut di atas adalah batal demi hukum (null and void). Dapat dibatalkan (voidable) berarti bahwa selama perjanjian tersebut belum diajukan pembatalannya ke pengadilan yang berwenang maka perjanjian tersebut masih tetap sah, sedangkan batal demi hukum (null and void) berarti bahwa perjanjian sejak pertama kali dibuat telah tidak sah, sehingga hukum menganggap bahwa perjanjian tersebut tidak pernah ada sebelumnya. (Ridwan Khairandy:2013)

Sebelum kontrak disusun atau sebelum transaksi bisnis berlangsung, biasanya terlebih dahulu dilakukan negosiasi awal. Negosiasi merupakan suatu proses upaya untuk mencapai kesepakatan dengan pihak lain. Dalam negosiasi inilah proses tawar menawar berlangsung. MoU merupakan pencatatan atau pendokumentasian hasil negosiasi awal tersebut dalam bentuk tertulis. MoU walaupun belum merupakan kontrak, penting sebagai pegangan untuk digunakan lebih lanjut di dalam negosiasi lanjutan atau sebagai dasar untuk melakukan studi kelayakan atau pembuatan kontrak. (Salim HS dan MS Abdullah:2017)

Pada asas hukum "kebebasan berkontrak" yang tercantum didalam BW Pasal 1338 ayat (1) yang berbunyi sebagai berikut: "Semua perjanjian yang di buat secara sah berlaku sebagai undang-undang bagi mereka yang membuatnya". dan pada ayat (3) nya mensyaratkan bahwa: "Suatu perjanjian harus dilaksanakan dengan itikad baik".

Sebuah itikad baik tidak hanya mengacu pada para pihak, tetapi juga harus mengacu pada nilai-nilai yang berkembang di masyarakat, karena itikad baik adalah bagian dari masyarakat. Sebuah itikad baik mencerminkan keadilan atau kepatutan masyarakat. Dengan makna seperti itu, menjadikan itikad baik sebagai suatu hal yang mengatur hubungan antar sosial setiap warga negara yang harus memiliki kewajiban untuk bertindak dengan iktikad baik terhadap semua warga negara. (Ridwan Khairandy:2007)

Itikad baik dalam pelaksanaan kontrak mengacu kepada itikad baik yang objektif. Standar yang digunakan dalam itikad baik objektif adalah standar yang objektif yang mengacu kepada suatu norma yang objektif.. Perilaku para pihak dalam kontrak harus diuji atas dasar norma-norma objektif yang tidak tertulis yang berkembang di dalam masyarakat. Ketentuan itikad baik menunjuk kepada norma-norma tidak tertulis yang sudah menjadi norma hukum sebagai suatu sumber hukum tersendiri. Norma tersebut dikatakan objektif karena tingkah laku tidak didasarkan pada anggapan para pihak sendiri, tetapi tingkah laku tersebut harus sesuai dengan anggapan umum tentang itikad baik tersebut. (Ridwan Khairandy:2013 
Jurnal Yustika

Vol. 24 No. 02, Des 2021

Halaman | 121

Prinsip Dalam

Berkontrak Pelaku

Olahraga

Sepakbola

Profesional Di

Indonesia

Nurharsya Khaer

Hanafie, Fatimah

Hidayahni Amin, Ririn

N.

Dengan demikian, kalau seorang seseorang bertindak dengan itikad baik menurut suatu standar objektif itikad baik yang didasarkan pada customary social expectation, kemudian orang yang lain akan bertindak yang sama kepada dirinya. Hal ini berlainan dengan konsep iktikad baik yang dianut hukum Kanonik yang lebih meletakkan iktikad baik sebagai suatu norma moral yang universal daripada sebagai suatu norma sosial. Dengan pendekatan yang demikian itu, maka makna kontekstual iktikad baik ditentukan oleh setiap individu karena, lest one breach a duty to God by failing or refusing to keep's promise, penting untuk bertindak dengan cara yang masuk akal atau rasional (reasonable) terhadap yang lain.

Terkait dengan penjelasan itikad baik di atas, dalam hal pelaksanaan suatu itikad baik dapat di terapkan dalam suatu kontrak baik kontrak umum maupun kontrak dalam olahraga profesional yang dalam hal ini pemenuhan gaji oleh klub kepada pemain yang belum dipenuhi padahal masa kontrak kerja pemain dalam perjanjian yang telah dibuat telah habis masa jangka waktunya. Klub menanggung hutang atas gaji pemain, pelatih, manajemen, serta untuk dana operasional hal ini sesuai dengan hal yang terdapat di dalam Statuta PSSI tahun 2016. Sesuai dengan ketentuan Pasal 1338 ayat (1) BW. Dan sebagaimana yang diatur dalam pasal $1234 \mathrm{BW}$, perjanjian merupakan hubungan hukum untuk berbuat sesuatu, memberikan sesuatu dan tidak berbuat sesuatu. Dimana pemain telah melaksanakan prestasinya, maka terdapat kewajiban bagi klub untuk memenuhi prestasinya juga terhadap pemain seperti yang telah disepakati sebelumnya. Perjanjian atau kontrak kerja pemain itu menimbulkan hubungan hukum karena sudah diatur dalam BW. Profesionalisme dalam arti normatif adalah segala hal sebagaimana diatur dalam kontrak kerja.

Sehingga hubungan antara pemain dan klub haruslah senantiasa di lakukan dengan asas profesionalitas dimana saling membutuhkannya kedua belah pihak dituangkan dalam sebuah kontrak kerjasama antara keduanya.

Dalam Artikel ini penulis coba mengidentifikasi permasalahan yang timbul yaitu prinsip-prinsip kontrak olahraga professional merupakan suatu kontrak bisnis atau hanya sebagai suatu kontrak kerja belaka.

\section{Metodologi Penelitian}

Dalam pnulisan artikel in, penulis menggunakan metode penelitian hukum empiris, yaitu metode yang berfungsi untuk melihat hukum dalam artian nyata dan meneliti bagaimana bekerjanya hukum di lingkungan masyarakat seperti prinsip kontrak dalam bisnis olahraga professional

Dalam penelitian ini, Penulis menggunakan metode penelitian hukum empiris dan melakukan penelitian dengan cara memperoleh literartur tentang hukum kontrak dan berbagai data tentang kontrak pelaku olahraga professional di Indonesia yang dibutuhkan guna pengolahan dalam menjawab permasalahan yang dikaji dalam penelitian, dan merupakan suatu cara yang digunakan dalam mengumpulkan data penelitian dan membandingkan dengan standar ukuran yang telah ditentukan. Berdasarkan hal ini Penulis menggunakan beberapa perangkat penelitian yang sesuai dalam metode penelitian guna memperoleh hasil yang maksimal. Dalam suatu penelitian hukum empiris, tentunya Penulis akan melakukan studi dokumen dengan cara melakukan studi kepustakaan yang akan menjadi bahan-bahan hukum pendukung Penulis dalam menyelesaikan Artikel ini 


\section{Pembahasan}

\section{1 Prinsip Kontrak dalam Hukum Perdata}

Prinsip kontrak dalam hukum perdata merupakam sebuah prinsip yang sama dalam berkontrakb dan berlaku di semua negara atau di mayoritas sistem hukum negara yang menggunakan sitem hukum Anglo Saxon. (Agus Yudho Hernoko:2010) Prinsip hukum umum dalam berkontrak dapat di inventarisasi dari berbagai hukum nasional untuk menemukan prinsip yang secara umum berlaku. (Subekti:2003)

Secara umum, dalam hukum kontrak internasional terdapat dua prinsip fundamental yang terdiri dari: 1) prinsip kedaulatan/supremasi hukum nasional; dan 2) Prinsip dasar kebebasan berkontrak (freedom of the contract atau the party's autonomy). Hal ini mencerminkan bahwa hukum nasional memegang peranan yang sangat penting dalam pembentukan kontrak internasional dan tidak dapat diganggu gugat keberadaannya. Kekuatan mengikat hukum nasional adalah mutlak dan kedudukannya adalah sebagai hukum yang paling diutamakan. Setiap subjek, objek, perbuatan, peristiwa, dan akibat hukum termasuk didalamnya transaksi dagang yang dituangkan dalam suatu kontrak yang terjadi dalam wilayah suatu negara tunduk secara mutlak pada hukum nasional tersebut.

Dalam sebuah kontrak terdapat konsep pembentukan dan penegakan kesepakatan antara para pihak. Kontrak bagi pelaku bisnis bergantung pada itikad baik orang lain saat merencanakan dan terlibat dalam bisnis. Tidak semua janji adalah diberlakukan sebagai kontrak. Sebuah kontrak telah didefinisikan sebagai perjanjian antara dua pihak atau lebih yang menciptakan kewajiban untuk melakukan atau tidak melakukan hal tertentu.

Dalam membuat sebuah kontrak pelaku olahraga professional khusunya sepakbola, dilakukan melalui proses penawaran atau proses negoisasi oleh salah satu pihak yang kemudian mendapatkan tawaran balik dari pihak lain. Negosiasi dapat dilanjutkan sampai para pihak mencapai kesepakatan dan memiliki kesamaan penafsiran, sehingga menciptakan sebuah kontrak yang mengikat dan dapat dilaksanakan. Dalam penawaran kontgrak tersebut masingmasing pihak di wakili oleh pihak yang di anggap kompoten dalam melakukan kontrak yaitu pihak klub di wakili oleh Direktur sedangkan pihak pemain di wakili oleh agen yang telah di tunjuk

Kontrak dalam olahraga tidak berbeda dari kontrak dalam kehidupan sehari-hari. Atlet menerima kompensasi untuk jasa mereka dengan gaji seperti orang lain. Bagian ini membahas sifat kontrak atlet profesional.

Mungkin hubungan yang paling penting dalam bidang olahraga profesional adalah bahwa antara individu pemain dan pemilik tim. Hubungan kontraktual ini diatur oleh prinsipprinsip dasar kontrak. yang berfungsi sebagai model kontrak kerja antara pemain dan pemilik. Model kontrak dapat dimodifikasi untuk mengakomodasi kebutuhan khusus dan bakat individu pemain.

\subsection{Prinsip Kontrak dalam Olahraga Profesional}

Dalam sebuah kontrak yang dianggap sah, apabila para pihak telah menyetujui semua fakta material kontrak dan pertemuan pikiran telah terjadi. "Sudah ditetapkan bahwa kontrak terjadi setelah para pihak telah mencapai kesepakatan. Kontrak adalah dasar hukum utama hubungan para pihak yang merupakan kekuatan kontrak yang telah disepakati para pihak dan merupakan undang-undang bagi mereka yang membuatnya. Oleh karena itu dalam penafsiran
Vol. 24 No. 02, Des 202

Halaman | 122

Prinsip Dalam

Berkontrak Pelaku

Olahraga

Sepakbola

Profesional Di

Indonesia

Nurharsya Khaer

Hanafie, Fatimah

Hidayahni Amin, Ririn

N. 
Jurnal Yustika

Vol. 24 No. 02, Des 2021

Halaman | 123

Prinsip Dalam

Berkontrak Pelaku

Olahraga

Sepakbola

Profesional Di

Indonesia

Nurharsya Khaer

Hanafie, Fatimah Hidayahni Amin, Ririn

kontrak, maka yang harus dijadikan dasar yang utama adalah teks dari kontrak yang bersangkutan. Jika kata-kata yang tertulis dalam klausula-klausula kontrak telah jelas, maka tidak diperkenankan para pihak menyimpang dari maksud klausula tersebut dengan cara melakukan penafsiran sendiri. Penafsiran kontrak hanya dibenarkan jika klausula-klausula kontrak ada yang tidak jelas atau bisa menimbulkan pengertian ganda.

Dalam sebuah kontrak antara pemain dan manajemen atau klub, persyaratan sahnya kontrak adalah penandatanganan komisioner atau badan otorisasi pelaksanaan kegaiatan keolahragaan.. Tanpa persetujuan tersebut, tandatangan pemain hanyalah tawaran tandingan. Kegagalan untuk mendapatkan tandatangan komisioner dianggap sebagai pelanggaran materi persetujuan berdasarkan pernyataan dalam kontrak. Tanpa tandatangan komisioner, penandatangan pemain adalah pembatalan tawaran.(Taryana Soekandar:2004)

Kedudukan atlet profesional telah menjadi diakui sebagai salah satu profesi yang paling menguntungkan secara finansiayang berarti mendapatkan keuntungan dalam bidang pendapatan atau keuangan dansponsor sering membayar ribuan dolar untuk seorang atlet untuk mempromosikan produknya. Kontrak olahraga dapat berdampak pada kehidupan ribuan orang. Banyak atlet didesak untuk meninggalkan statusnya amatir untuk diberikan kompensasi atas jasa mereka sebagai seorang profesional. Kontrak kerja dengan atlet harus selalu dilakukan secara tertulis dan harus mencakup persyaratan oleh atlet seperti menjanjikan untuk menahan diri dari tindakan-tindakan tertentu, yang membahayakan

Menurut pasal 55 UU Nomor 3/2005 tentang Sistem Keolahragaan Nasional, menjelaskan tentang pelaku olahraga Profesional :adalah orang yang menjalankan profesi sesuai dengan keahliannya yang memenuhi persyaratan seperti, lulus tes medis dan mendapat surat keterangan pelepasan hak sebagai atlet amatir dan mempunyai hak untuk didampingi oleh, antara lain, manajer, pelatih, tenaga medis, psikolog, dan ahli hukum; dan mendapatkan pendapatan yang layak.

Sebagian besar kontrak olahraga berupa kontrak di mana kesepakatan para pihak dibuktikan dengan kata-kata mereka, baik lisan ataupun secara tertulis. Hampir tidak ada kontrak yang lebih tersirat dalam industri olahraga. Kontrak tersirat adalah kontrak di mana perjanjian tersebut tidak dibuktikan dengan kata-kata tertulis atau lisan, tetapi oleh tindakan dan perilaku para pihak.(Ibrahim Nathaniela:2011)

Berdasarkan penjelasan di atas, penulis membagi prinsip kontrak dalam olahraga profesional terdiri dari Prinsip Kepercayaan, Prinsip Keadilan, Prinsip Kepastian Hukum, Prinsip Perlindungan Hukum, dan Prinsip Ganti kerugian sebagai bagian dari temuan penulis terkait prinsip-prinsip kontrak umum dan prinsip-prinsip kontrak dalam olahraga profesional antara lain (Nurharsya Khaer Hanafie:2016)

1. Prinsip Kepercayaan, Prinsip ini mengandung pengertian bahwa setiap orang yang akan mengadakan perjanjian akan memenuhi setiap prestasi yang diadakan diantara mereka dibelakang hari dikarena kedua belah pihak telah mengetahui kemampuan pemain yang akan dikontrak dan pemain mengetahui target atau prestasi klub dalam berkompetisi sehingga dalam pembuatan kontrak kedua belah pihak saling mempercayai.

2. Prinsip keadilan, Prinsip ini menjelaskan bahwa subjek hukum yang mengadakan perjanjian mempunyai kedudukan yang sama, serta mempunyai hak dan kewajiban yang sama dalam hukum. Mereka tidak boleh dibeda-bedakan antara satu sama lainnya, walaupun subjek hukum itu berbeda warna kulit, agama, dan ras sehingga 
dalam pembuatan kontrak nantinya bersifat adil dan kedua belah pihak mampu memenuhi prestasi tanpa adanya pihak yang merasa tertekan dalam pembuatan kontrak

3. Prinsip Kepastian Hukum dalam suatu Perjanjian mengandung kepastian hukum. Kepastian ini terungkap dari kekuatan mengikatnya perjanjian, yaitu sebagai undang-undang bagi yang membuatnya.

4. Prinsip Perlindungan Hukum, Prinsip ini mengandung makna antara para pihak harus dilindungi oleh hukum. Namun, yang perlu mendapat perlindungan itu adalah pihak pemain karena pihak ini berada pada posisi yang lemah dan sangat mungkin dirugikan dalam suatu pembuatan kontrak.

5. Prinsip Kompensasi/Ganti Rugi, Prinsip ini mengandung makna bahwa setiap pihak yang melakukan suatu perjanjian kerja dalam jangka waktu tertentu, dan belum berakhirnya masa waktu kontrak tersebut salah satu pihak memutus kontrak pihak lain yang dalam hal ini terjadi pihak klub memutus kontrak pemain dan tidak lagi melaksanakan kewajibannya untuk membayarkan hak pemain dalam sisa waktu kontraknya berakhir maka pihak yang telah melakukan wanprestasi tersebut wajib memberikan ganti rugi kepada pihak yang di rugikan akibat dari adanya pemutusan kontrak sepihak.

Kelima Prinsip tersebut diatas melahirkan Konsep Kontrak dalam Olahraga Profesional ini yang dilatar belakangi oleh teori Mengenai kapan suatu kesepakatan kehendak terjadi sehingga saat itu pula kontrak dianggap telah mulai berlaku yang secara akademis, terdapat berbagai macam teori tentang kontrak, yang masing-masing mencoba menjelaskan berdasarkan pengelompokannya dan kriterianya masing-masing. (Atiyah:1983)

Hal tersebut tercermin dari adanya Konsep Hukum Keolahragaan sebagai bagian dari Sistem Hukum Nasional merupakan suatu kesatuan hukum dari unsur hukum yang saling berhubungan dan bekerjasama sebagai suatu kesatuan untuk mencapai tujuan tertentu yang terdiri dari Peraturan mengenai tingkah laku manusia dalam pergaulan masyarakat., Peraturan diadakan oleh badan - badan resmi yang berwajib., Peraturan bersifat memaksa. Dan Sanksi bagi pelanggar peraturan tersebut

\subsection{Karakteristik Kontrak dalam Olahraga Profesional}

Kontrak dalam olahraga profesional mendefinisikan hak dan tanggung jawab partisipan yang beragam dalam bisnis olahraga profesional. Mungkin hubungan yang paling penting dalam bidang olahraga profesional adalah bahwa antara individu pemain dan pemilik tim. Hubungan kontraktual ini diatur oleh prinsip-prinsip dasar kontrak. Penulis menjelaskan bahwa kontrak dalam olahraga profersional di namakan Standar Kontrak Pemain (SKP) Standar kontrak pemain sebelumnya adalah apendiks, yakni kontrak pekerjaan yang menspesifikkan hak dan kewajiban. yang dapat dimodifikasi jika pemain tertentu memiliki kemampuan "unik (kelebihan yang dapat meningkatkan nilai jual seperti berteknik tinggi dalam urusan olahraga dan juga berwajah tampan sehingga mempunyai nilai jual untuk produk iklan pihak swasta) yakni kemampuan untuk mengeksplorasi berdasarkan kemampuan teknik dan melalui popularitas yang sudah ada. Semakin "unik" pemain semakin besar kemampuannya untuk memodifikasi SKP dengan melampirkan modifikasi standar, seperti: tidak ada potongan, tidak ada perdagangan atau pasal kehadiran. Manajemen biasanya tidak memberikan apapun kepada pemainnya dalam hal ini, kecuali telah disepakati dalam kontrak kedua belah pihak.
Vol. 24 No. 02, Des 202

Halaman | 124

Prinsip Dalam

Berkontrak Pelaku Olahraga

Sepakbola

Profesional Di

Indonesia

Nurharsya Khaer

Hanafie, Fatimah

Hidayahni Amin, Ririn

N. 
Jurnal Yustika

Vol. 24 No. 02, Des 2021

Halaman | 125

Prinsip Dalam

Berkontrak Pelaku

Olahraga

Sepakbola

Profesional Di

Indonesia

Nurharsya Khaer

Hanafie, Fatimah

Hidayahni Amin, Ririn

N.

Kontrak pelaku olahraga terdiri dari beberapa macam perjanjian dan terdapat dalam semua Olahraga Profesional salah satunya dalam sepakbola, antara lain : Kontrak antara Pemain profesional dan Management Klub Profesional, Kontrak antara Pelatih Profesional dengan Klub Profesional dan Kontrak antara Pemain Profesional dengan pihak ketiga (swasta) dalam hal right image dan Iklan. (Walter T Chamion:2005)

Dalam konteks perancangan suatu kontrak bagi pelaku olahraga profesional maka para pihak yang dimaksud adalah para pelaku olahraga profesional yang terdiri dari Atlet dan Pelatih yang diwakili oleh Agent dengan Klub peserta kompetisi olahraga profesional yang berstatus profesional adalah badan hukum berbentuk Perseroan Terbatas (selanjutnya disebut PT) yang diwakili oleh pihak direksi atau management.

Pihak yang diberikan kuasa dalam melakukan kontrak olahraga profesional disebut juga dengan Agent dimana, kuasa yang diberikan tersebut di berikan melalui suatu perjanjian yang dituangkan dalam kontrak dan diatur dalam pasal 1799 BW. Pihak yang dapat menjadi Agent adalah pihak yang paham dan mengerti tentang management olahraga serta mengetahui tentang hukum kontrak dan mendapatkan rekomendasi dari asosiasi organisasi olahraga.. Kontrak dengan demikian merupakan sarana untuk memastikan apa yang hendak dicapai oleh para pihak dapat diwujudkan dalam sebuah hubungan kerja dan di tuangkan dalam Kontrak Bisnis

Dalam melindungi kepentingan persepakbolaan professional, FIFA sendiri telah membuat acuan yang termuat dalam. CL No.1171 diatur secara jelas mengenai klausula-klausula yang wajib diatur dalam sebuah kontrak antara pesepakbola professional dan klub professional. Dalam hal ini, Pengawasan Isi Kontrak pelaku olahraga profesional khusunya sepakbola adalah merupakan salah satu perlindungan kepada pesepakbola professional dimana, dengan sistem pengawasan secara langsung oleh Institusi yang diakui oleh asosiasi sepakbola dalam hal ini PSSI.

Dalam point 1.2 CL No.1171 menjelaskan bahwa Setiap klub yang resmi harus menerima fotokopi kontrak dan satu fotokopi harus diberikan ke Perkumpulan Profesional dan/atau Asosiasi Anggota untuk pendaftaran berdasarkan ketetapan kubu sepakbola yang kompeten) Esensi dari ketentuan ini adalah kewajiban dari PSSI dalam melakukan pengawasan terhadap kontrak professional yang tidak hanya bertujuan melindungi pesepakbola tetapi juga mengawasi apakah klausula di dalam kontrak tersebut sesuai dengan statuta dan peraturan organisasi FIFA dan PSSI serta ketentuan hukum tenaga kerja yang berlaku di Indonesia.

Klub Profesional Sebagai Pihak Dalam Kontrak Profesional Pesepakbola dan Sehubungan dengan status klub professional, ketentuan Point 1.4 CL No.1171 dengan jelas menyatakan sebagai berikut: Perjanjian menyatakan nama klub resmi yang lengkap (termasuk nomor pendaftaran) dan alamat lengkap juga nama, nama keluarga, dan alamat orang yang secara resmi mewakili klub.

Pemain sepakbola yang profesional hanya dapat dipakai oleh klub sepakbola dan persatuan resmi. Persatuan tersebut didefinisikan sebagai Peraturan-peraturan/Manual Izin Klub Nasional sebagai pemain yang legal. Pemain tersebut harus menjadi anggota asosiasi sepakbola nasional yang langsung atau tidak langsung dan atau perkumpulan profesional dan didaftarkan sebagaimana mestinya. Persatuan resmi lainnya tidak dapat menggunakan kontrak pemain tanpa persetujuan dari organisasi sepakbola nasional yang kompeten seperti PSSI dan FIFA"

Kontrak yang dilaksanakan baik antara pemain profesional dengan klub profesional, antara pemain profesional dengan pihak ketiga (swasta) maupun antara pihak klub profesional 
dengan pihak ketiga (swasta) termasuk kontrak dalam hal pembagian hak siar pertandingan, merupakan bagian yang melekat dari transaksi bisnis baik dalam skala besar maupun kecil, baik domestik maupun internasiomal. Fungsinya sangat penting menjamin bahwa seluruh harapan yang dibentuk dari janji-janji para pihak dapat terlaksana dan terpenuhi. Dalam hal terjadi pelanggaran maka terdapat kompensasi yang harus dibayar. Kontrak dengan demikian merupakan sarana untuk memastikan apa yang hendak dicapai oleh para pihak dapat diwujudkan dalam sebuah hubungan kerja (Gardiner Simon:2001)

Di sisi lain point 11.2 CL No.1171 mengatur Klub dan pemain harus mematuhi statuta, peraturan termasuk kode etik, keputusan FIFA, Persekutuan, anggota asosiasi dan juga Perkumpulan Profesional (jika perlu) yang membentuk bagian tak terpisah dalam perjanjian ini. Kedua belah pihak memberikan apresiasi mereka melalui pemberian tanda tangan.

Setelah melihat draft kontrak pemain sepakbola profesional yang telah di standarisasi oleh Badan Liga Indonesia dan PT Liga Indonesia tampak bahwa para pemain sepakbola Profesional di Indonesia dalam melakukan kontrak dengan klub tanpa di wakili oleh Agent atau manager sebagai perwakilan pemain yang seharusnya memahami tentang hukum kontrak atau perjanjian serta prinsip-prinsip yang terkandung dalam suatu kontrak atau perjanjian serta memahami keinginan dan talenta pemain yang diwakilinya agar pemain tersebut hanya berkonsentrasi pada penguatan fisik dan pengembangan teknik dan skill tanpa memikirkan halhal administratif yang di tuangkan dalam kontrak (Statuta Fifa:2016)

Mengenai Isi dari Draft kontrak tersebut, tampak tidak adanya pasal mengenai asuransi bagi si pemain dimana hal tersebut sangatlah di butuhkan oleh pemain untuk melaksanakan kewajibannya sebagai pemain profesional untuk klub yang mengontraknya selama jangka waktu kontrak tersebut berdurasi. Hal ini sangat bertentangan dengan ketentuan atau regulasi yang dikeuarkan ole FIFA dimana Asuransi merupakan hal wajib yang harus dituangkan dalam sebuah kontrak dalam olahraga sepakbola profesional.

Ihwal kontrak image rights harus diatur dalam kontrak dengan klub. Klub ini memiliki hak untuk menggunakan image dari pemain sehubungan dengan promosi Club, kegiatan bermain, merek klub, dan produk atau jasa terkait sepak bola. Selain itu, ini tidak melarang atau mencegah pemain masuk ke dalam pengaturan lain dalam kaitannya dengan periklanan, pemasaran, atau promosi.

Perjanjian ini (Perjanjian) dibuat pada (tanggal) oleh dan antara Athletic Equipment Manufacturer (selanjutnya disebut AEM), sebuah perusahaan yang diatur dan berada di bawah hukum negara bagian (nama negara), dengan kantor utama yang terletak di (alamat jalan, kota, daerah, negara, kode pos), disebut di sini sebagai AEM, dan (Nama Olahragawan dari (alamat jalan, kota, daerah, negara, kode pos), yang selanjutnya disebut Athlete.

AEM setuju bahwa baik penggunaan Identifikasi Atlet maupun item yang digunakan dalam kaitannya dengan Identifikasi atlet akan dibuat berdasarkan Perjanjian ini kecuali dan sampai hal yang sama telah disetujui oleh atlet. Atlet setuju bahwa setiap materi, iklan atau sebaliknya, diajukan untuk persetujuan sebagaimana diatur dalam Perjanjian ini mungkin dianggap oleh AEM telah disetujui berdasarkan Perjanjian ini jika sama tidak disetujui secara tertulis dalam (jumlah hari) hari kerja setelah diterimanya material. Atlet setuju bahwa materi yang disampaikan berdasarkan Perjanjian ini tidak akan masuk akal untuk ditolak.

Setelah berakhirnya Masa Kontrak, semua hak-hak AEM dengan penggunaan Identifikasi Olahragawan akan berhenti sama sekali dan AEM tidak akan kemudian menggunakan atau merujuk Identifikasi Olahragawan dalam iklan atau promosi dengan cara 
Jurnal Yustika

Vol. 24 No. 02, Des 2021

Halaman | 127

Prinsip Dalam

Berkontrak Pelaku

Olahraga

Sepakbola

Profesional Di

Indonesia

Nurharsya Khaer

Hanafie, Fatimah Hidayahni Amin, Ririn

apapun. Hal ini lebih lanjut setuju bahwa setelah berakhirnya Masa Kontrak, AEM tidak akan mengiklankan, mempromosikan, mendistribusikan atau menjual barang apapun sehubungan dengan penggunaan setiap nama, tokoh, desain, logo, merek dagang atau nama dagang yang serupa atau sesuai dengan Identifikasi atlet..

Mengenai Isi dari Draft kontrak tersebut, tampak tidak adanya pasal mengenai asuransi bagi si pemain dimana hal tersebut sangatlah di butuhkan oleh pemain untuk melaksanakan kewajibannya sebagai pemain profesional untuk klub yang mengontraknya selama jangka waktu kontrak tersebut berdurasi. Hal ini sangat bertentangan dengan ketentuan atau regulasi yang dikeuarkan ole FIFA dimana Asuransi merupakan hal wajib yang harus dituangkan dalam sebuah kontrak dalam olahraga sepakbola profesional.

Ihwal kontrak image rights harus diatur dalam kontrak dengan klub. Klub ini memiliki hak untuk menggunakan image dari pemain sehubungan dengan promosi Club, kegiatan bermain, merek klub, dan produk atau jasa terkait sepak bola. Selain itu, ini tidak melarang atau mencegah pemain masuk ke dalam pengaturan lain dalam kaitannya dengan periklanan, pemasaran, atau promosi.

AEM setuju bahwa baik penggunaan Identifikasi Atlet maupun item yang digunakan dalam kaitannya dengan Identifikasi atlet akan dibuat berdasarkan Perjanjian ini kecuali dan sampai hal yang sama telah disetujui oleh atlet. Atlet setuju bahwa setiap materi, iklan atau sebaliknya, diajukan untuk persetujuan sebagaimana diatur dalam Perjanjian ini mungkin dianggap oleh AEM telah disetujui berdasarkan Perjanjian ini jika sama tidak disetujui secara tertulis dalam (jumlah hari) hari kerja setelah diterimanya material. Atlet setuju bahwa materi yang disampaikan berdasarkan Perjanjian ini tidak akan masuk akal untuk ditolak.

Setelah berakhirnya Masa Kontrak, semua hak-hak AEM dengan penggunaan Identifikasi Olahragawan akan berhenti sama sekali dan AEM tidak akan kemudian menggunakan atau merujuk Identifikasi Olahragawan dalam iklan atau promosi dengan cara apapun. Hal ini lebih lanjut setuju bahwa setelah berakhirnya Masa Kontrak, AEM tidak akan mengiklankan, mempromosikan, mendistribusikan atau menjual barang apapun sehubungan dengan penggunaan setiap nama, tokoh, desain, logo, merek dagang atau nama dagang yang serupa atau sesuai dengan Identifikasi atlet..

Perjanjian ini bukan merupakan dan tidak boleh ditafsirkan sebagai asosiasi, kemitraan, joint venture atau hubungan prinsipal dan agen atau majikan dan karyawan antara Athlete dan AEM. Tidak satu pihak pun harus memiliki hak untuk mewajibkan atau mengikat pihak lain dengan cara apapun, dan kecuali sebagaimana diatur dalam Perjanjian ini, tidak ada yang terkandung dalam Perjanjian ini akan memberikan, atau dimaksudkan untuk memberikan, hak apapun untuk Pihak ketiga.

Terakit hal tersebut diatas, maka kontrak pelaku olahraga profesional dapat lah di kategorikan sebagai sebuah kontrak bisnis karena pada dasarnya apa yang di perjanjikan dalam suatu kontrak olah raga profesional merupakan suatu produk dari sebuah kontrak bisnis. Apabila dikaji aspek pasar tentunya kita akan mengkaji dari berbagai aktivitas bisnis yang hidup dan berkembang dalam sebuah pasar (market). Di dalam berbagai market tersebut terjadi perjanjian jual beli, sewa-menyewa, beli sewa, dll. Untuk itulah di perlukan pengetahuan tentang prinsip-prinsip kontrak dalam olahraga profesional sebagai sebuah kontrak bisnis yang dapat meminimalisasi terjadinya suatu sengketa kontrak pelaku olah raga profersional dan kalaupun terjadi sengketa maka penyelesaiannya dapat dilakukan sesuai dengan penyelesaian sengketa secara bisnis yang dapat berupa penyelesaian sengketa menggunakan Alternative 
Dispute Resolution (ADR) yang juga dapat menyelesaikan sengketa menggunakan Mediasi dan Arbitration

Jurnal Yustika Vol. 24 No. 02, Des 2021

\section{Kesimpulan}

Dari penjelasan tersebut di atas dapat disimpulkan bahwa Prinsip berkontrak bagi pelaku olahraga professional khususnya olah raga sepakbola haruslah memenuhi unsur-unsur atau prinsip-prinsip yang terdapar dalam hukum kontrak dimana salah satunya adalah prinsip itikad baik dari para pihak dan di karenakan kedua belah pihak sebagai pelaku olahraga professional di Indonesia dalam berkontrak harus di dasarkan kepada itikad baik karena tanpa itikad baik dari kedua belah pihak atau para pelaku olahraga professional maka kontrak tersebut tidak akan sesuai dengan apa yang di harapkan kedua belah pihak Ini merupakan konsep itikad baik subjektif yang mengacu kepada suatu standar moral subjektif karena ia didasarkan pada kejujuran individu

Kontrak pelaku olahraga terdiri dari beberapa macam perjanjian dan terdapat dalam semua Olahraga Profesional salah satunya dalam sepakbola, antara lain : Kontrak antara Pemain profesional dan Management Klub Profesional, Kontrak antara Pelatih Profesional dengan Klub Profesional dan Kontrak antara Pemain Profesional dengan pihak ketiga (swasta) dalam hal right image dan Iklan Dalam konteks perancangan suatu kontrak bagi pelaku olahraga profesional maka para pihak yang dimaksud adalah para pelaku olahraga profesional yang terdiri dari Atlet dan Pelatih yang diwakili oleh Agent dengan Klub peserta kompetisi olahraga profesional yang berstatus profesional adalah badan hukum berbentuk Perseroan Terbatas (selanjutnya disebut PT) yang diwakili oleh pihak direksi atau management. Pihak yang diberikan kuasa dalam olahraga profesional disebut juga dengan Agent dimana, kuasa yang diberikan tersebut di berikan melalui suatu perjanjian yang dituangkan dalam kontrak dan diatur dalam pasal 1799 BW. Pihak yang dapat menjadi Agent adalah pihak yang paham dan mengerti tentang management olahraga serta mengetahui tentang hukum kontrak dan mendapatkan rekomendasi dari asosiasi organisasi olahraga tempat pihak tersebut. Dan untuk kontrak tersebut dinamakan dengan Kontrak Bisnis dalam olahraga profesional
Halaman | 128

Prinsip Dalam

Berkontrak Pelaku Olahraga Sepakbola Profesional Di Indonesia

Nurharsya Khaer Hanafie, Fatimah Hidayahni Amin, Ririn 


\section{Daftar Referensi}

\begin{tabular}{l} 
Jurnal Yustika \\
Vol. 24 No. 02, Des 2021 \\
\hline Halaman I 129 \\
Prinsip Dalam \\
Berkontrak Pelaku \\
Olahraga \\
Sepakbola \\
Profesional Di \\
Indonesia \\
Nurharsya Khaer \\
Hanafie, Fatimah \\
Hidayahni Amin, Ririn \\
N.
\end{tabular}

Buku

Agus Yudha Hernoko. (2010). Hukum Perjanjian Prinsip Proporsionalitas dalam Kontrak Komersial. Jakarta: Kencana Prenada Media Group.

Atiyah. (2006). The Law of Contract. London: Clarendon Press.

Champion Jr Walter T. (2014). Sports Law: Cases, Documents and Materials (Aspen Select). Wolters Kluwer Law \& Business.,

Ibrahim A. Nathaniela. (2011). 300 contoh surat perjanjian kontrak. Jakarta: Gudang Ilmu.

Mariam Darus Badrulzaman. (2005). Aneka Hukum Bisnis. Bandung: Alumni.

Munir Fuady. (2002). Hukum Bisnis dalam Teori dan Praktek. Bandung: PT. Citra Aditya Bakti.

Ridwan Khairandy. (2013). Makna, Tolok Ukur, Pemahaman, dan Sikap Pengadilan di Indonesia terhadap Iktikad Baik dalam Pelaksanaan Kontrak (tidak dipublikasikan).

Ridwan Khairandy, R (2015). Kebebasan Berkontrak Pacta Sunt Servanda Versus Itikad Baik. Yogyakarta, FH-UII Press.

H. Salim, dan H, Abudallah. (2017). (Notaris)Perancangan Kontrak dan Memorandum of Understanding (MoU). Jakarta: Sinar Grafika.

Subekti. (2003). Pokok-Pokok Hukum Perdata. Jakarta: Intermasa.

Sudargo Gautama. (2006). Indonesian Business Law. Bandung: Citra Aditya Bakti.

T. Soenandar. (2004). Prinsip-Prinsip UNIDROIT Sebagai Sumber Hukum Kontrak dan Penyelesaian Sengketa Bisnis Internasional. Jakarta: Sinar Gafika.

Walter T. Champion. (2014) Sport Law (Fourth Edition). Texas: Texas Southern University.

Walter T. Champion. Sports Ethics for Sports Management Professionals/ Edition 2. Jones \& Bartlett Learning.

Simon Gardiner. (2001). Sport Law. London: Cavendish Publishing Limited.

\section{Artikel Jurnal}

John Klein (1993), Good Faith in International Transaction, The Liverpool Law Review, XV (2).

Eric M. Holmes. (1978). A Contractual Study of Commercial Good faith: Good Faith Disclosure in Contract Formation. University of Pittsburg Law Review. 39 (3), 1978.

Jason Randal Erb. (1994). The Implied Covenant of Good Faith and Fair Dealing in Alaska: One Court's License to Override Contractual Expectations, Alaska Law Review, 35-66

John Klein. (1993). Good faith in international transactions. Liverpool Law Review Volume 15, 115141.

Bambang Sutiyoso. (2013). Penafsiran Kontrak Menurut Kitab Undang-Undang Hukum Perdata dan Maknanya Bagi Para Pihak yang Bersangkutan. Jurnal Hukum Ius Quia Iustum 2(20), 207-233. doi: https://doi.org/10.20885/iustum.vol20.iss2.art3

Peraturan Perundang-Undangan

Undang-Undang Dasar Negara Republik Indonesia 1945 Tambahan Lembaran Negara

Republik Indonesia, No. 75, 1959)

Kitab Undang-Undang Hukum Perdata (BW) 
Undang-Undang Nomor 3 Tahun 2005 tentang Sistem Keolahragaan Nasional Tambahan

Lembaran Negara Republik Indonesia Tahun 2005 Nomor

Undang-Undang Nomor 40 Tahun 2007 tentang Perseroan Terbatas Tambahan Lembaran

Negara Republik Indonesia Tahun 2007 Nomor 106

Regulations Governing the Application of the Statutes Standing Orders of the Congress, FIFA Statuten 2015

Pedoman Dasar PSSI, Statuta PSSI 2019

\begin{tabular}{r} 
Jurnal Yustika \\
Vol. 24 No. 02, Des 2021 \\
\hline Halaman I 130 \\
Prinsip Dalam \\
Berkontrak Pelaku \\
Olahraga \\
Sepakbola \\
Profesional Di \\
Indonesia \\
Nurharsya Khaer \\
Hanafie, Fatimah \\
Hidayahni Amin, Ririn \\
$\mathrm{N}$.
\end{tabular}

